\title{
Struktur kepribadian tokoh Lilian dalam novel Pink Cupcake karya Ramya Hayasrestha Sukardi (Sastra anak dalam perspektif psikoanalisis Sigmund Freud) (The personality structure of Lilian's character in the Pink Cupcake novel by Ramya Hayasrestha Sukardi (Children's literature in Sigmund Freud's psychoanalytic perspectives))
}

\section{Anita Kurnia Rachman ${ }^{\mathrm{I}^{*}}$, Fitri Resti Wahyuniarti ${ }^{\mathrm{b} 2}$}

aProgram Studi Pendidikan Bahasa dan Sastra Indonesia, Fakultas Pendidikan Ilmu Sosial dan Humaniora, IKIP Budi Utomo, J1. Simpang Arjuno No I4, Malang, Indonesia

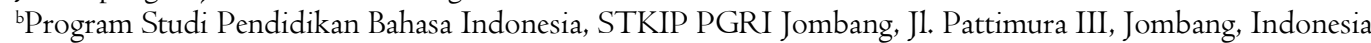
Ianita27rachman@gmail.com, fitriresti86@gmail.com

*Corresponding author: anita27rachman@gmail.com

\begin{tabular}{l}
\hline Sejarah Artikel Diterima: 2 Agustus 202I $\quad$ Direvisi: I2 Oktober 202I \\
ABSTRAK \\
\hline \hline Sastra anak tidak hanya ditulis oleh orang dewasa tetapi juga ditulis oleh anak-anak. Kecil-Kecil Punya Karya (KKPK) \\
merupakan salah satu sastra anak yang ditulis oleh anak. Penelitian ini menggunakan novel Pink Cupcake Karya Ramya \\
Hayasrestha Sukardi. Novel ini dipilih karena tokoh Lilian merupakan anak yang manja dan sulit bersosialisasi. Tujuan \\
penelitian ini, untuk mendeskripsikan keadaan psikologis tokoh Lilian yang terdapat dalam novel anak Pink Cupcake Karya \\
Ramya Hayasrestha Sukardi pada aspek struktur kepribadian tokoh yang meliputi id, ego, dan superego. Penelitian ini \\
merupakan penelitian kajian pustaka dengan pendekatan psikoanalisis Sigmund Freud. Data penelitian berupa teks yang \\
terdiri atas monolog, dialog, dan narasi yang mengambarkan sifat, tingkah laku, perbuatan, dan perkataan dalam bentuk \\
paparan bahasa yang mendeskripsikan kepribadian tokoh Lilian dalam novel anak Pink Cupcake Karya Ramya Hayasrestha \\
Sukardi. Teknik pengumpulan data dilakukan dengan membaca, mengidentifikasi, dan mengklasifikasikan data yang \\
mengandung aspek struktur kepribadian, meliputi id, ego, dan superego tokoh Lilian. Instrumen dalam penelitian ini, yaitu \\
peneliti sebagai instrumen utama dan kodifikasi data sebagai instrumen pendukung. Analisis data dilakukan dengan \\
mengklasifikasi data, mendeskripsikan hasil klasifikasi data, menganalisis data, dan menginterpretasikan data. Hasil \\
penelitian menunjukkan bahwa struktur kepribadian yang meliputi id, ego, dan superego tokoh Lilian berkembang dengan \\
baik sesuai dengan perkembangan tokoh Lilian. Perkembangan ini membuat tokoh Lilian mampu beradaptasi dengan \\
kondisi di sekitarnya serta mampu menumbuhkan sikap positif.
\end{tabular}

\section{Kata Kunci Psikoanalisis Sigmund Freud, Sastra anak, Struktur kepribadian}

\section{ABSTRACT}

Children's literature is not only written by adults but also written by children. Little Ones and Their Works (KKPK) is one of the children's literature written by children. This research uses the novel Pink Cupcake by Ramya Hayasrestha Sukardi. The reason for choosing this novel is because the main character in this novel is a spoiled child and is not sociable.. Things change when a girl appears and then turns out to be a friendship fairy. The problem in this research is how the personality structure of Lilian's character in the children's novel Pink Cupcake by Ramya Hayasrestha Sukardi is. It includes id, ego, and superego. This research is a literature review research with Sigmund Freud's psychoanalytic approach. The data of this study are texts consisting of monologues, dialogues, and narrations that describe the nature, behavior, actions, and words in the form of language exposures that describe the personality of the main character of the child in the children's novel Pink Cupcake by Ramya Hayasrestha Sukardi. Data collection techniques were carried out by reading, identifying, and classifying data containing psychoanalytic aspects. The instrument in this study was the researcher as the main instrument and the codification of the data as a supporting instrument. Data analysis was carried out by classifying data, describing the results of data classification, analyzing data, and interpreting data. The results showed that the character's personality structure is dynamic. The three elements of the personality structure are interrelated with each other and form a totality, although the distribution of energy use is sometimes unbalanced.

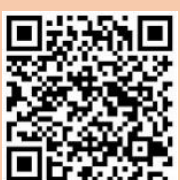

Copyright@202I, Anita Kurnia Rachman, Fitri Resti Wahyuniarti This is an open access article under the CC-BY-3.0 license

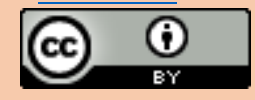

\begin{tabular}{ll}
\hline Keywords & Sigmund Freud's psychoanalysis, Children's literature, Personality structure \\
\hline \hline How to Cite & $\begin{array}{l}\text { Rachman, A. K., \& Wahyuniarti, F. R. (202I). Struktur kepribadian tokoh Lilian dalam novel Pink } \\
\text { Cupcake karya Ramya Hayasrestha Sukardi (Sastra anak dalam perspektif psikoanalisis Sigmund Freud). }\end{array}$ \\
\hline
\end{tabular}


KEMBARA: Jurnal Keilmuan, Bahasa, Sastra dan Pengajarannya (e-Journal), 7(2), 490-507. https://doi.org/I0.22219/kembara.v7i2.17625

\section{PENDAHULUAN}

Karya Sastra merupakan hasil tiruan kehidupan yang dituangkan ke dalam cerita dengan berbagai kisah yang dialami oleh para tokohnya. Karya sastra menurut Rumaf, et al (2018) berisi fenomena batin yang tampak dalam sikap dan perilaku tokoh. Karya sastra tidak hanya diperuntukkan bagi orang dewasa tetapi juga dapat dinikmati oleh anak-anak. Karya sastra untuk anak tidak hanya ditulis orang dewasa, namun juga ditulis oleh anak-anak. Sastra anak menurut Faidah (2018) merupakan karya yang ditulis oleh orang dewasa dan diperuntukkan oleh anak atau yang ditulis anak dan dinikmati oleh anak. Sastra anak yang ditulis oleh anak mengambarkan tentang cerita dan kehidupan sehari-hari seoarang anak. Sastra anak merupakan ungkapan yang dialami anak. Hal ini seperti penyataan Kurniawan (20I3) bahwa sastra anak ceritanya berkorelasi dengan dunia anak, bahasa yang digunakan sesuai dengan perkembangan dan emosi anak. Sastra anak memiliki persamaan dan perbedaan dengan sastra untuk orang dewasa. Karakteristik sastra untuk orang dewasa dan sastra untuk anak memiliki kesamaan dalam hal pengungkapan dan penggunaan bahasa. Sastra anak merupakan sastra yang ditujukan kepada anak agar anak mendapatkan banyak manfaat dan berguna bagi kehidupan perkembangan intelektual, emosional, dan karakter anak.

Pemilihan bacaan untuk anak harus sesuai dengan perkembangan anak. Pemilihan sastra untuk anak perlu adanya perhatian tentang perbedaan buku bacaan anak dan dewasa. Buku bacaan untuk dewasa tidak begitu saja dapat diberikan kepada anak. Hal ini karena terdapat kendala keterbatasan yang menyangkut isi maupun unsur kebahasaan. Sastra anak menawarkan kesenangan dan pemahaman tentang dunia bagi anak. Dunia anak menurut Rosid (202I) menjadi dunia paling menyenangkan dalam fase kehidupan manusia. Pada fase ini terdapat dunia hayal dan dunia bermain penuh warna. Sastra anak memiliki sifat yang imajinatif. Hakikat sastra anak sesuai dengan dunia alam kehidupan anak-anak yang berbeda dengan dunia orang dewasa. Anak-anak sebagai pembaca memiliki fantasi yang akan berkembang dan mampu menerima cerita baik nyata atau fantasi. Isi cerita anak mencerminkan kehidupan anak seperti pernyataan Efendi (2019) substansi dari sastra anak harus selaras dengan dunia dan kehidupan anak yang menjadi milik mereka, bukan milik orang dewasa karena sifat sastra anak lebih menonjolkan usur fantasi. Unsur imajinasi yang terdapat dalam sastra anak menurut Nurgiyantoro (2010) akan memantik tumbuh kembangnya kreativitas. Hal inilah yang disebut creative thinking. Oleh karena itu, aspek imajinasi anak perlu diarahkan sejak dini supaya berkembang secara wajar dan maksimal, salah satunya melalui bacaan sastra.

Kecil-Kecil Punya Karya (KKPK) merupakan salah satu sastra anak yang dapat dibaca oleh anak. KKPK menjadi wadah berbagai karya anak dalam bentuk kumpulan cerpen maupun novel yang ditulis sendiri oleh anak. Tema-tema yang terdapat dalam KKPK merupakan tema-tema yang tidak jauh dari kehidupan anak. Seting yang digunakan dalam cerita anak merupakan seting yang telah dikenal anak, seperti rumah, sekolah, dan taman. Selain itu, ada juga seting yang diceritakan berasal dari imajinasi anak, seperti tempat-tempat yang ada di kerajaan. Bahasa yang digunakan merupakan bahasa yang sederhana, lugas, dan apa adanya yang sering digunakan anak. Penggambaran tokoh dalam KKPK juga sederhana, mulai dari tokoh-tokoh yang sudah dikenal seperti orang tua, saudara, teman-teman, guru, pembantu, sampai tokoh-tokoh yang hanya ada dalam imajinasi anak, seperti peri, putri, pangeran, raja, ratu, pengawal, dan dayang yang hanya ada di istana. Penggambaran karakter para tokoh digambarkan sesuai dengan kenyataan di sekitar anak, namun ada juga yang diberi karakter sesuai dengan imajinasi anak. Cerita-cerita yang ditulis dalam KKPK sesuai dengan pernyataan Munaris (2020) yang menyebutkan sastra anak merupakan ungkapan perasaan yang dialami anak dan dituangkan dalam bentuk tulisan untuk dinikmati anak-anak. Membaca cerita dalam KKPK dapat dilakukan oleh anak secara mandiri atau dengan pendampingan orang tua. Pendampingan ini dilakukan jika anak belum mampu memahami kata atau bahasa yang terdpat dalam cerita. Pendampingan ini seperti yang disampaikan oleh Sarumpaet (2010) 
sastra anak adalah sastra yang dibaca anak "dengan bimbingan dan pengarahan anggota dewasa suatu masyarakat”. Pink Cupcake Karya Ramya Hayasrestha Sukarni merupakan salah satu karya KKPK yang dapat dibaca oleh anak. Cerita sederhana ditulis oleh gadis kecil berusia I2 tahun yang bernama Ramya Hayasrestha Sukarni ini bertemakan persahabatan.

Karakteristik yang terdapat dalam sastra anak Pink Cupcake Karya Ramya Hayasrestha Sukarni seperti yang dijelaskan Rumidjan (2013) dapat dilihat dari dua segi, yaitu dari kebahasaan dan kesastraan. Segi kebahasaan dapat dilihat dari struktur kalimat, pilihan kata, dan gaya bahasa. Struktur kalimat masih sederhana, berupa kalimat tunggal, kalimat berita, kalimat tanya, atau kalimat perintah sederhana. Pilihan kata menggunakan kata-kata yang sudah dikenal oleh anak-anak. Gaya bahasa masih sedikit karena lebih menggunakan kata-kata konkret. Bacaan yang baik adalah bacaan yang sesuai dengan fase perkembangan anak. Bacaan yang akan dibaca anak harus mengandung tema yang mendidik seperti pernyataan Lukens (dalam Faidah, 2018) secara garis besar genre sastra anak dibagi menjadi lima, yaitu fiksi, non fiksi, puisi, sastra tradisional, dan komik. Fiksi anak berbentuk prosa menampilkan cerita hayalan/imajinatif. Pemilihan karya sastra yang tepat bagi anak akan membantu orang tua dalam menanamkan nilai dan norma yang baik. Hal ini tentunya akan berpengaruh pada perkembangan, sikap, dan perilaku anak dalam kehidupan keluarga dan masyarakat. Sastra anak menurut Ikhwan (2013) menjadi alat efektif dalam mengajarkan nilai, norma, dan perilaku luhur masyarakat. Sastra anak dikemas dalam bentuk yang berbeda dari sastra orang dewasa, sehingga dapat diterima dan dipahami dengan baik. Sastra anak Pink Cupcake Karya Ramya Hayasrestha Sukarni menurut Puryanto (dalam Ikhwan, 2013) merupakan lukisan kehidupan anak yang bersifat imajinatif ke dalam bentuk struktur bahasa anak. Sastra anak ditujukan untuk anak dan dapat berkisah tentang apa saja, bahkan yang menurut orang dewasa tidak masuk akal. Misalnya, berkisah tentang binatang yang dapat berbicara, bertingkah, berpikir dan berperasaan seperti manusia. Imajinasi dan emosi anak menurut Efendi, et al (2019) mampu menerima cerita secara wajar menurut jangkauan pemahaman anak.

Tokoh anak yang bernama Lilian dalam Pink Cupcake Karya Ramya Hayasrestha Sukarni merupakan anak yang memiliki kehidupan seperti anak pada umumnya. Lilian yang masuk kelas satu SD membutuhkan bimbingan dari orang tuanya untuk dapat bersosialisasi dengan lingkungannya karena Lilian merupakan anak pendiam dan tidak mudah bergaul. Anak menurut Rosid (202I) merupakan sesorang yang masih memerlukan bimbingan dalam tingkah lakunya. Anak merupakan manusia yang berusia antara 6 sampai I2 tahun. Anak menurut Sarumpaet (20I0) merupakan seseorang yang memerlukan segala fasilitas, perhatian, dorongan, dan kekuatan untuk membuatnya tumbuh sehat menjadi mandiri dan dewasa. Sastra anak yang ditulis oleh anak, tokohnya merupakan karya imajinatif yang tumbuh dalam diri anak. Selain itu, anak mulai mampu mengambarkan tokoh-tokoh yang terdapat di sekitarnya yang disukai atau tidak disukai. Persoalan penggambaran tokoh dalam cerita sangat menarik untuk dikaji (Anggraini, 2016). Penggambaran, tokoh dan bahasa dalam sastra anak cukup sederhana sesuai dengan tingkat umur dan perkembangan jiwa dari penulis (anak). Kreativitas yang ditampilkan anak-anak dalam menulis tidak terlepas dari perkembangan psikologi anak. Penciptaan tokoh pada cerita anak tidak terlepas dari karakter-karakter yang berhubungan dengan psikologi. Psikologi merupakan ilmu yang mempelajari kejiwaan manusia tidak terkecuali kejiwaan anak. Pengetahuan mengenai psikologi perkembangan anak merupakan bagian yang harus dipahami ketika berhadapan dengan dunia anak (Sarumpaet, 2010).

Kajian tentang sastra anak menjadi topik yang menarik karena dituntut untuk lebih memahami dunia anak yang sederhana. Sastra anak menurut Efendi, et al (2019) masih dianggap tidak terlalu populer dibandingkan dengan sastra dewasa, padahal dalam penerapannya, sastra anak dapat berperan penting terhadap perkembangan kognisi, emosi, dan keterampilan anak. Anak sebagaimana halnya orang dewasa membutuhkan informasi tentang segala sesuatu yang ada di dunia dan kejadian-kejadian yang terjadi setiap harinya (Gunawan \& Putro, 2020). Selain membutuhkan informasi, anak membutuhkan perhatian, pengakuan, pengukuhan, dan penghargaan. Berbagai keperluan anak, terutama keperluan akan informasi, harus diusahakan untuk dipenuhi. Anak berhak untuk memperoleh hal-hal tersebut untuk pengembangan 
identitas diri dan kepribadiannya. Cerita dalam sastra anak mendorong dan mengajari anak dalam mengenali kepribadiannya dalam mengendalikan berbagai emosi.

Anak memiliki kepribadian yang unik sesuai dengan fase perkembangannya. Kepribadian menurut Khasanah, et al (202I) berasal dari kata "pribadi” yang berarti diri sendiri atau perseorangan. Kepribadian merupakan bagian dari jiwa yang membangun keberadaan manusia menjadi satu kesatuan. Kejiwaan pada manusia menekankan pada dua aspek seperti yang dijelaskan Ja'far (20I5) kepribadian ditekankan pada dimensi biososial manusia yang dihubungkan dengan aspek sosial dan psikologis. Tokoh-tokoh yang terdapat dalam cerita anak diciptakan oleh pengarang dengan kepribadian-kepribadian yang berbeda. Pemahaman tentang kepribadian yang terjadi pada tokoh anak dan pengetahuan tentang psikologi ini diperlukan karena menurut Prahasita (20I4) dibutuhkan untuk memahami aspek kejiwaan yang dialami oleh tokoh dalam cerita tidak terkecuali cerita anak. Hal ini perlu dipahami bahwa setiap anak memiliki kepribadian yang berbeda dan bersifat unik (Sembiring, et al, 2018). Kepribadian ini menjadi penanda atau ciri-ciri khusus. Memahami kepribadian berarti memahami aku, diri, self, atau memahami manusia seutuhnya (Alwisol dalam Abraham, 2017).

Kajian sastra memiliki sifat interdisipliner mempertemukan ilmu sastra dengan berbagai macam cabang ilmu lainnya. Psikologi sastra sebagai salah satu cabang ilmu yang mempertemukan sastra dengan psikologi telah digunakan untuk membaca dan menginterprestasikan karya sastra, pengarang, dan pembacaan melalui konsep dan teori psikologi. Hal ini mengakibatkan sastra dan psikologi memiliki hubungan yang erat secara tidak langsung dan fungsional. Psikologi merupakan roh, jiwa atau daya hidup yang mempelajari kejiwaan seseorang. Psikologi berasal dari bahasa Yunani seperti yang dijelaskan Minderop (2010) psyche, yang berarti jiwa dan logos berarti ilmu. Psikologi merupakan ilmu yang mempelajari gejala dan kegiatan-kegiatan jiwa, serta tingkah laku manusia maupun hewan, baik di alam kesadaran maupun ketidaksadaran. Sastra dan psikologi memiliki objek yang sama, yaitu kehidupan manusia. Psikologi sastra memiliki peranan penting dalam pemahaman sastra karena memiliki kelebihan, yaitu (I) psikologi sastra digunakan untuk mengaji secara mendalam pada aspek perwatakan; (2) penggunaan pendekatan psikologi sastra dapat memberi umpan-balik kepada peneliti tentang masalah perwatakan yang dikembangkan; (3) digunakan untuk menganalisis karya sastra yang memiliki banyak masalah-masalah psikologis. Hubungan psikologi dan sastra bersifat fungsional karena mempelajari keadaan jiwa manusia. Perbedaannya, dalam psikologi gejala riil, sedangkan dalam sastra bersifat imajinatif. Sastra sebagai ungkapan jiwa, sastra adalah wakil jiwa lewat bahasa. Dengan demikian, dapat diartikan sastra tidak mampu melepaskan diri dari aspek psikis seperti yang dijelaskan Setyorini (2017) bahwa tujuan psikologi sastra memahami aspek-aspek kejiwaan yang terkandung dalam karya sastra.

Kepribadian atau keadaan psikologi yang terdapat dalam sastra anak Pink Cupcake Karya Ramya Hayasrestha Sukarni dapat dianalisis menggunakan psikoanalisis Sigmund Freud. Dasar pemikiran psikoanalisis pertama kali seperti yang disampaikan Minderop (2010) bahwa teori psikoanalisis adalah disiplin ilmu yang dicetuskan oleh Sigmund Freud tahun 1900-an. Freud menyebutkan sebagian besar kepribadian manusia berasal dari proses yang tidak disadari. Freud menyebutkan proses tidak sadar meliputi pemikiran, rasa takut, keinginan yang tidak disadari tetapi membawa pengaruh terhadap perilakunya. Implus masa kanak-kanak yang dilarang dan dihukum oleh orang tua dan masyarakat yang berasal dari naluri pembawaan. Implus yang tidak disadari mendapat jalan pelampiasan melalui mimpi, kekeliruan bicara atau keseleo lidah, lelucon, lamunan, cara kebiasaan, dan bentuk artistik serta sastra. Memasuki dunia Freud berarti memasuki wilayah motivasi gairah, perasaan bersalah yang dipendam, keinginan yang tidak terungkapkan, dan konflik antara keinginan dan kejiwaan yang tidak disadari.

Teori psikoanalisis berhubungan dengan fungsi dan perkembangan mental manusia tidak terkecuali anak-anak. Hal ini menjadi bagian dari psikologi yang memberikan kontribusi besar dan dijadikan sebagai dasar ilmu psikologi yang dikenal sekarang. Freud membedakan tiga struktur dalam hidup psikis berupa proses kesadaran, prasadar, dan proses tidak sadar atau ketidaksadaran. Sistematika kepribadian Freud (dalam Alwisol, 20II) dikelompokkan menjadi tiga aspek, yakni (I) struktur kepribadian, (2) dinamika kepribadian, dan (3) perkembangan kepribadian. Peneliti dalam penelitian ini 
hanya memfokuskan pada struktur kepribadian yang terdapat dalam tokoh anak Lilian yang terdapat pada cerita anak Pink Cupcake Karya Ramya Hayasrestha Sukarni. Struktur kepribadian yang akan dianalisis dalam penelitian ini sesuai dengan pernyataan Freud (dalam Dani \& Adji, 202I) terdiri atas tiga aspek, yaitu (I) Id, (2) Ego, dan (3) Superego.

Aspek id yang terdapat di dalam struktur kepribadian merupakan pembawaan sejak lahir. Id berhubungan dengan proses fisik yang bertujuan mendapatkan energi psikis. Energi ini berguna untuk mengoperasikan sistem pada aspek struktur kepribadian yang lain. Id menurut Yarta (2012) merupakan lapisan paling dasar dari struktur kepribadian. Hidup psikis janin sebelum lahir dan bayi yang baru lahir terdiri dari id saja. Aspek id merupakan sistem original dalam jiwa, dari aspek ini tumbuh kedua aspek lain. Aspek id berisikan hal-hal yang dibawa sejak lahir, atau unsur-unsur biologis. Id (aspek biologis) merupakan sistem kepribadian yang paling dasar, sistem yang di dalamnya terdapat naluri-naluri bawaan seperti yang disebutkan Nawawi \& Ahsana (202I) id adalah aspek biologis yang merupakan sistem original kepribadian tempat bersumbernya energi psikis. Fungsi aspek $i d$ adalah berpegang kepada prinsip 'kenikmatan', yaitu mencari keenakan dan menghindari diri dari ketidakenakan. Id menurut Husin (2017) dikenal memiliki prinsip kesenangan (Pleasure Principle) karena selalu meredam ketegangan dengan mengejar kepuasan. Proses pleasure principle melalui du acara, yaitu. (I) Refleks Actions/Tindakan Refleks, merupakan reaksi otomatis sejak lahir. (2) Primery Process/Proses Primer, merupakan reaksi dalam bentuk mengkhayal yang bertujuan untuk mengurangi tegangan. Id tidak mampu membedakan khayalan dengan kenyataan, tidak mampu membedakan benar dan salah.

Ego merupakan aspek kedua dari struktur kepribadian. Ego memiliki peran dalam memilih keinginan yang dilaksanakan berdasarkan prioritas. Ego berkembang dari id, sehingga tujuan ego untuk memuaskan id. Ego memiliki kemampuan untuk mengenali realita dan memiliki prinsip realita (reality principle). Ego memiliki kemampuan untuk menunda kenikmatan sampai ditemukan objek yang nyata dan dapat memuaskan kebutuhan. Ego menurut Maftuhah (2018) adalah aspek sosiologis daripada kepribadian, merupakan wakil dari nilai-nilai tradisional serta cita-cita masyarakat yang ditafsirkan orang tua kepada anak-anaknya, berbentuk perintah dan larangan. Ego berperan penting dalam memastikan dorongan Id yang dapat diekspresikan dengan cara yang dapat diterima dalam dunia nyata. Ego mengekspresikan dorongan-dorongan yang ingin dipuaskan oleh Id dengan cara yang sesuai dengan realitas (Syam \& Rosaliza, 2020).

Superego merupakan aspek ketiga dari struktur kepribadian. Prinsip yang dimiliki superego, yaitu prinsip idealistik yang berlawanan dengan id. Superego mengambarkan kekuatan moral dan etik kepribadian. Superego menurut Rosmila, et al (2020) dianggap sebagai aspek moral kepribadian. Fungsi superego menentukan sesuatu itu benar atau salah, pantas atau tidak, susila atau tidak, sesuai dengan moralitas yang berlaku di masyarakat. Sifat superego nonrasional dalam menuntut kesempurnaan. Superego bersifat keras dalam menanggapi ego, baik yang telah dilakukan maupun baru dalam pikiran. Superego memiliki tiga fungsi; (I) mendorong ego menggantikan tujuan-tujuan realistik dengan tujuan moralistik, (2) merintangi impuls id terutama impuls seksual dan agresif yang bertentangan dengan standar nilai masyarakat, (3) mengejar kesempurnaan. Superego menurut Yarta, et al (2012) mempunyai fungsi menentukan sesuatu benar atau salah, pantas atau tidak, susila atau asusila, sesuai dengan lingkungan masyarakat. Fungsi pokok super ego, yaitu (a) merintangi impuls-impuls id, terutama impuls seksual, (b) mendorong ego untuk mengejar hal-hal yang moralitas, dan (c) mengejar kesempurnaan. Maftuhah (2018) menjelaskan bahwa superego lebih merupakan kesempurnaan dari kesenangan. Aspek moral dari kepribadian dan fungsi pokok superego menentukan apakah sesuatu benar atau salah. Dengan demikian pribadi dapat bertindak sesuai dengan moral masyarakat. Superego menurut Sartika (2017) mewakili moralitas dan otoritas orang tua, yaitu suara hati ketika berbuat salah. Superego yang sebagian disadari namun lebih besar tidak disadari, menilai aktivitas id, memberikan perasaan menyenangkan, yaitu kebanggaan dan kepuasan saat berhasil melakukan sesuatu, dan perasaan buruk, yaitu perasaan bersalah dan malu saat kita melanggar peraturan. 
Pink Cupcake Karya Ramya Hayasrestha Sukarni merupakan salah satu cerita yang sangat menarik karena di dalamnya terdapat imajinasi pengarang, yaitu kehadiran peri persahabatan. Peri yang menyamar menjadi manusia dengan nama Lavender dan bersahabat dengan Lilian seorang anak yang tidak mudah bergaul. Novel ini mengambarkan keadaan psikologi seorang anak yang manja dan harus beradaptasi di sekolah. Rasa emosi dan tidak dihiraukan orang lain juga merupakan gambaran psikologi tokoh Lilian dalam cerita ini. Munculnya tokoh lain yang membawa sifat/keadaan psikologi yang lebih baik, sedikit demi sedikit mampu mengubah psikologi tokoh Lilian. Gambaran psikologi tokoh dalam cerita digambarkan dengan baik oleh pengarang, sehingga membuat pembaca merasa ada di dunia anak dan berimajinasi bahwa dunia ini sebenarnya sederhana.

Berdasarkan hasil pemaparan di atas, penelitian tentang sastra anak dan pendekatan psikologi sastra bukanlah kajian yang pertama dilakukan. Sebelumnya telah ada kajian tentang sastra anak dan psikologi sastra, yaitu (I) "Struktur Kepribadian Tokoh Utama dalam Novel Anak Bungsu Karya Soesilo Toer" (Dani \& Adji, 202I). Penelitian ini menghasilkan struktur kepribadian tokoh Aida. Struktur Kepribadian Aida berawal dari kejadian pelecehan seksual yang dilakukan seorang serdadu. Id Aida muncul ketika dia mengalami rasa rindu kepada kekasihnya. Hal ini membuat dia mencari hiburan dan mengalami pelecehan. Rasa rindu dan takut yang ia alami terkadang muncul dalam mimpi Aida. Ego Aida memunculkan rasa takut dan keinginan lari dari serdadu. Sedangkan super ego Aida, yaitu kesabaran dan mempertahankan harga diri ketika berada di kota yang jauh dari tempat kelahirannya. (2) "Pemanfaatan Sastra Anak-anak dalam Evaluasi Pembelajaran Bahasa Indonesia di Sekolah Dasar" (Zubaidah, 200I). Penelitian ini merupakan penelitian sastra anak genre puisi. Puisi dalam penelitian ini digunakan untuk evaluasi pembelajaran sastra di jenjang SD. Pengajaran sastra di SD tidak hanya menekankan aspek latihan tetapi juga pembentukan watak dan sikap. Pengajaran sastra mempunyai beberapa unsur penting, yaitu penikmatan, pemanfaatan, dan sikap untuk menghargai orang lain. Pembelajaran sastra ini membuat siswa mampu menikmati dan memanfaatkan karya sastra untuk mengembangkan kepribadian, memperluas wawasan kehidupan, serta meningkatkan pengetahuan dan kemampuan berbahasa. (3) "Analisis Semiotika pada Bacaan Sastra Anak Raden Legowo: Pahlawan dari Hutan Perewangan Karya Sulistiati dengan Perspektif Religiositas” (Gunawan \& Putro, 2020). Penelitian ini merupakan penelitian sastra anak yang memfokuskan pada dongeng anak menggunakan analisis semiotik dengan perspektif religiositas. Hasil penelitian secara religiositas dapat disimpulkan jika semua karakter yang terdapat dalam dongeng memiliki keimanan. Akan tetapi, ketika memasuki tahap keteringatan dan kepasrahan beberapa karakter tidak memilikinya terlebih karakter Villain. Hanya Timun Emas dan Palupi yang digambarkan memiliki kualitas religi yang tinggi dilihat dari cara mereka berdoa, bersyukur. Manifestasi religiositas Jawa yang dimiliki tokoh meliputi rela, menerima, sabar, hormat, dan rukun. Tokoh Villain meskipun memiliki keimanan namun tidak memiliki manifestasi religiositas. Motif penggerak dalam mencapai objek (kebahagiaan) merupakan dasar pembeda antara dua kubu karakter dan menjadi penentu akhir cerita. Maka dari hasil tersebut, dapat ditemukan bahwa makna tanda (niat baik akan mengalahkan niat jahat, dan niat buruk akan menghasilkan sesuatu yang buruk).

Berdasarkan kajian penelitian terdahulu, peneliti menemukan perbedaan dan persamaan dengan penelitian yang sekarang. Pada penelitian terdahulu terdapat persamaan pada pendekatan yang digunakan, yaitu pendekatan psikologi sastra menggunakan psikoanalisis Sigmund Freud untuk menganalisis struktur kepribadian tokoh utama. Perbedaan yang ditemukan, yaitu pada objek penelitian. Penelitian terdahulu menggunakan karya sastra berbentuk novel yang ditujukan untuk orang dewasa. Pada penelitian yang sekarang menggunakan sastra anak yang berbentuk novel anak dan ditulis oleh anak. Penelitian terdahulu yang kedua memiliki persamaan pada topik pembahasan, yaitu sastra anak. Letak perbedaan terdapat pada tujuan penelitian dan objek penelitian. Penelitian terdahulu menggunakan sastra anak yang berbentuk puisi untuk mengevaluasi hasil pembelajaran sastra anak di sekolah dasar. Sedangkan pada penelitian sekarang menggunakan sastra anak untuk memahami struktur kepribadian tokoh anak dalam novel anak. Penelitian terdahulu yang ketiga memiliki persamaan dengan penelitian yang sekarang, persamaan itu terletak pada objek penelitian, yaitu sastra anak. Sedangkan perbedaannya terdapat pada fokus penelitian, 
pendekatan, dan struktur kajian. Penelitian terdahulu menggunakan sastra anak yang difokuskan pada cerita rakyat, menggunakan struktur kajian Greimas dan menggunakan pendekatan semiotik perspektif religiositas Jawa.

Kontribusi penelitian sastra anak untuk dunia sastra, yaitu bahwa sastra anak yang ditulis oleh anak dapat dianalisis untuk memahami perkembaangan psikologi anak, baik menggunakan psikoanalisis Sigmund Freud atau menggunakan teori yang lain. Sastra anak dapat digunakan sebagai media pembelajaran di sekolah-sekolah untuk menanamkan pendidikan karakter. Selain itu, sastra anak yang ditulis anak dapat digunakan sebagai motivasi untuk mengajak anak menulis cerpen atau novel anak. Oleh sebab itu, permasalahan yang akan dibahas dalam penelitian ini, yaitu (I) bagaimana struktur kepribadian Id tokoh Lilian dalam novel Pink Cupcake karya Ramya Hayasrestha Sukardi? (2) Bagaimana struktur kepribadian Ego tokoh Lilian dalam novel Pink Cupcake karya Ramya Hayasrestha Sukardi? (3) Bagaimana struktur kepribadian superego tokoh Lilian dalam novel Pink Cupcake karya Ramya Hayasrestha Sukardi?

\section{METODE}

Jenis penelitian ini merupakan penelitian kajian pustaka yang mengaji aspek struktur kepribadian pada tokoh Lilian yang terdiri atas id, ego, dan superego. Pendekatan yang digunakan dalam penelitian ini, yaitu pendekatan psikologi sastra, yaitu suatu pendekatan yang mempertimbangkan segi-segi kejiwaan dan menyangkut batiniah tokoh Lilian dalam novel Pink Cupcake karya Ramya Hayasrestha Sukardi. Alasan pemilihan penelitian ini karena menggunakan hasil argumentasi penalaran keilmuan yang memaparkan hasil kajian pustaka dan hasil olah pikir peneliti mengenai suatu masalah/topik kajian. Fokus kajian penelitian ini, yaitu struktur kepribadian tokoh Lilian dalam novel anak Pink Cupcake Karya Ramya Hayasrestha Sukardi. Bagian-bagian yang diteliti dari psikoanalisis Freud, yaitu struktur kepribadian yang meliputi id, ego, dan superego. Data penelitian berupa teks yang mendeskripsikan struktur kepribadian tokoh Lilian yang terdiri atas monolog, dialog, dan narasi yang mengambarkan sifat, tingkah laku, perbuatan, dan perkataan tokoh. Teks berupa paparan-paparan bahasa yang dibagi dalam bentuk data struktur kepribadian tokoh Lilian, yaitu id, ego, dan superego. Sumber data berupa novel anak Pink Cupcake karya Ramya Hayasrestha Sukardi yang diterbitkan oleh Dar Mizan tahun 2010. Novel yang digunakan adalah novel cetakan ke-2 dengan jumlah halaman I59.

Pengumpulan data dilakukan dengan teknik studi dokumentasi karena sumber data penelitian ini bersifat dokumentasi, sedangkan datanya merupakan hasil pemahaman. Dalam mengumpulkan data peneliti membuat kriteria struktur kepribadian tokoh berdasarkan psikoanalisis Sigmund Freud. Kriteria itu digunakan sebagai pedoman dalam mengklasifikasi dan mengidentifikasi struktur kepribadian. Peneliti melakukan pengamatan data dengan teknik dokumentasi pada novel anak Pink Cupcake karya Ramya Hayasrestha Sukardi. Proses memahami dilakukan melalui kegiatan membaca. Proses pengumpulan data menggunakan cara (I) peneliti melalukan kegiatan membaca berulang-ulang, (2) peneliti mengidentifikasi dan mencatat data sesuai dengan aspek yang dikaji, yaitu id, ego, dan superego, dan (3) peneliti mengklasifikasikan data tentang struktur kepribadian. Peneliti sebagai human instrument, berfungsi menetapkan fokus penelitian, memilih sumber data, melakukan pengumpulan data, analisis data, menafsirkan data, dan membuat kesimpulan atas temuan. Instrumen pendukung dalam penelitian ini berupa kodifikasi data.

Data yang berwujud paparan-paparan bahasa yang berhubungan dengan struktur kepribadian tokoh Lilian, dianalisis menggunakan prosedur analisis data model interaktif Miles dan Huberman dengan adaptasi sesuai dengan kebutuhan dan kondisi penelitian. Prosedur yang ditempuh dalam analisis data sebagai berikut. 


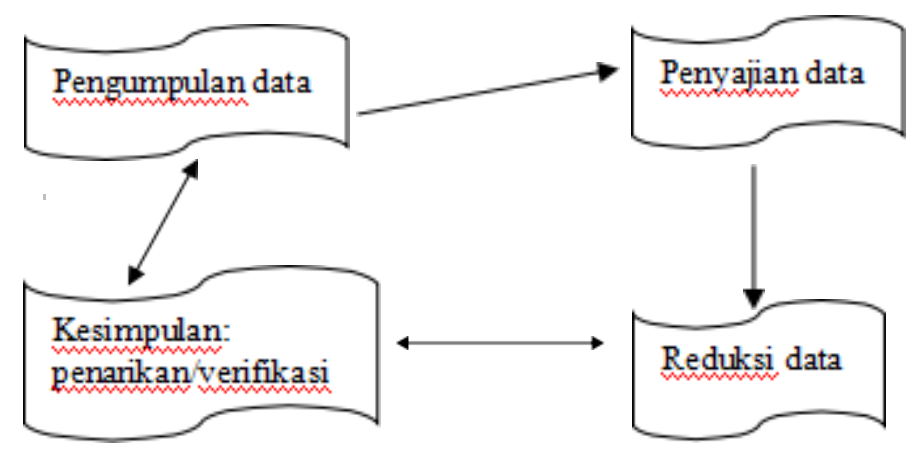

Gambar I Analisis Data Miles dan Huberman

Sumber: Miles, Hubberman dan Saldana (20I4)

\section{Bagan I Analisis Data Miles dan Huberman}

1) Data diperoleh dari hasil membaca secara berulang-ulang novel anak yang berjudul Pink Cupcake karya Ramya Hayasrestha Sukardi.

2) Mengklasifikasikan dan mendeskripsikan data yang diperoleh dari aspek struktur kepribadian yang terdiri atas id, ego, dan superego.

3) Menganalisis data sesuai dengan masalah yang telah dirumuskan dan menyimpulkan hasil analisis.

\section{HASIL DAN PEMBAHASAN}

\section{Struktur Kepribadian Id Tokoh Lilian}

Lilian merupakan anak kecil yang selalu ingin bersenang-senang dan memenuhi semua yang diinginkan. Dalam mengejar kepuasan untuk mengurangi ketegangan, Lilian memenuhinya dengan cara membayangkan sesuatu yang diinginkannya. Hal itu terdapat dalam kutipan berikut.

"Kita buat pesta lho, Yah! Nanti, mau makan-makan sampai malam. Kan, besok libur!" teriak Lilian penuh antusias. (SK-I/48).

Kutipan (I) menunjukkan bahwa ketegangan akibat rasa lapar yang dirasakan oleh Lilian dipenuhi dengan membayangkan akan makan-makanan yang enak-enak setelah ayahnya pulang. Suprapto (2018) menjelaskan bahwa wujud pemenuhan id terlihat dari keinginan-keinginannya untuk memperoleh kebahagiaan. Membayangkan merupakan bentuk peralihan id untuk mengejar kesenangan yang dilakukan oleh Lilian. Nawawi \& Ahsana (202I) karena merupakan bagian cara kerja kepribadian id untuk mencari kenikmatan/kesenangan. Wujud dari id dapat berhubungan dengan subjektivitas/keadaan batin individu (perasaan, pikiran persepsi, gambaran, ingatan, gagasan, atau halusinasi). Perasaan pada diri tokoh dapat berupa rasa senang, sedih, bahagia, dan iri. Hal itu terdapat dalam kutipan berikut.

(2) Lilian terlihat sedikit iri. Dia berkata, "Oh keren sekali! Memang, kamu suka menari balet, ya?” (SK-I/I9)

Kutipan (2) menunjukkan perasaan yang terdapat dalam diri Lilian, yaitu rasa iri yang dialami Lilian ketika melihat tas teman barunya yang bergambar sepatu balet. Rasa ini muncul akibat subjektivitas Lilian terhadap benda milik temanya, sehingga muncul rasa iri karena tidak memiliki benda yang sama. Rasa iri pada anak seusia Lilian merupakan hal wajar dan banyak dirasakan oleh anak-anak yang lain. Pada fase perkembangan ini menurut Darmiah (2019) anak mampu memahami bahwa satu peristiwa dapat menimbulkan reaksi emosional yang berbeda pada beberapa orang. Perasaan Lilian juga cenderung pada perasaan marah dan jengkel ketika yang diinginkan tidak dapat terpenuhi. Perasaan ini muncul pada anak yang selalu ingin merasa senang, bahagia, dan tidak ingin mengalami kesusahan. Keadaan ini sangat 
berhubungan dengan perkembangan emosi anak. Perkembangan emosi anak menjadi kompleks dan cepat berubah seperti yang dijelaskan Ilham (2020) bahwa perkembangan emosi pada anak di tandai perubahan biologis dari perilaku baik berupa nafsu, perasaan, dan keadaan mental yang tidak terkontrol. Kondisi emosi yang kompleks dan cepat berubah yang dialami Lilian berhubungan dengan pola asuh orang tua. Hal ini menimbulkan pengaruh pada kondisi tokoh Lilian yang dijelaskan oleh Sari (2020) bahwa pola asuh orang tua memiliki pengaruh penting terhadap perkembangan emosi anak. Dimana perkembangan emosi merupakan faktor yang paling dominan dalam mempengaruhi keberhasilan (kesuksesan) di masa yang akan datang, dengan mengajari anak keterampilan emosi mereka akan lebih mampu untuk mengatasi berbagai masalah. Rasa marah dan kesal Lilian terdapat dalam kutipan berikut.

(3)

Lilian mengangguk, seolah-olah dia tidak apa-apa. Padahal, dia capek hati kepada mama yang terlambat menjemput (SK-I/23).

Pukul setengah dua belas siang, anak kelas III sampai kelas IV sudah boleh pulang. Harusnya kan, aku sudah dijemput dari tadi, keluh Lilian dalam hati. Hati Lilian sedih sekali. Teman-teman sekelasnya sudah pulang semua. Sementara, dia belum juga dijemput mamanya. Lilian tidak menjawab. Perasaannya masih sesak (SK-I/24-25)

"Tapi, kan Lilian jadi nunggu lama! Masa, hanya Lilian sendiri anak kelas satu yang

(5) belum dijemput! Orang tua teman-teman Lilian pada cepat, kok ngejemputnya!" seru Lilian. Muka Lilian mendadak merah padam, menahan jengkel (SK-I/26)

(6) Lilian bertopang dagu menghadap kaca. Mulutnya terkunci rapat. Dia merasa retak hatinya. (SK-I/55)

Kini, Lilian tambah cemberut. Tangannya sebenarnya sudah kesemutan karena bertopang

(7) dagu seperti itu. Lilian gengsi, dong, mau menurunkan tangannya. Gaya ngambek, kan, harus seperti itu! Hehehe... (SK-I/55)

Kutipan (3) dan (4), menunjukkan bahwa sebagai anak kelas I SD, Lilian ingin setiap hari dijemput oleh mama dan datang tepat waktu. Namun, kenyataannya mama justru terlambat menjemput ke sekolah dan itu membuat Lilian merasa kesal karena harus menunggu lama. Darmiah (2019) menjelaskan rasa marah adalah ekspresi yang lebih sering diungkapkan pada anak-anak jika dibandingkan dengan rasa takut. Hal ini karena rangsangannya menimbulkan rasa marah lebih banyak. Pada usia dini anak-anak merasakan bahwa kemarahan merupakan cara efektif untuk memperoleh perhatian/memenuhi keinginan mereka. Lilian semakin jengkel ketika melihat siswa kelas III dan IV sudah pulang. Wujud dari sikap kesal dan marah ini salah satunya ditunjukkan dengan aksi diam ketika diajak berbicara. Diharapkan dengan sikap ini, mamanya akan tahu bahwa Lilian sedang kesal dan marah.

Untuk memenuhi hal tersebut, id dapat menggunakan berbagai cara, seperti mendesak, irasional, impulsif, mementingkan diri sendiri dan suka kesenangan. Kutipan (5), (6), dan (7) menunjukkan kemarahan Lilian dengan cara tidak menjawab pertanyaan mama ketika diajak berbicara. Mama memberi penjelasan mengapa datang terlambat. Hal ini membuat Lilian semakin marah kepada mama karena berpikir mamanya sengaja datang. Lilian memiliki sikap mementingkan diri sendiri. Hal ini muncul pada diri anak-anak ketika semua hal yang diinginkan harus selalu terpenuhi. Nawawi \& Ahsana (202I) id akan berusaha mereduksikan dengan tujuan menghilangkan rasa ketidaknyamanan. Indikasi berfungsinya $i d$, yaitu keinginan untuk menghindarkan diri dari ketidaknyamanan dan keinginan untuk memperoleh kenikmatan. Proses ini merupakan bagian dari perkembangan emosi anak. Dewi, et al (2020) menyebutkan perkembangan emosi menjadi sebuah krisis dalam perkembangan anak dan merupakan faktor yang dominan dalam mempengaruhi tingkah laku individu.

Dalam mengurangi ketegangan, seorang individu dapat juga melakukan tindakan refleks. Tindakan refleks tersebut meliputi bersin, berkedip, dan rasa kaget dari panggilan atau tepukan. Tindakan ini merupakan tindakan yang tidak direncanakan dan terjadi begitu saja. Tindakan refleks yang dilakukan Lilian terdapat dalam kutipan berikut. 
(8) Lilian mencoba memejamkan matanya. Tapi, dia belum mengantuk. (SK-I/3I)

"Namamu siapa, sih?" seseorang menepuk pundak Lilian dari belakang. Lilian merasa

(9) kaget. Segera dia menoleh dengan mulut yang masih berisi permen. Ternyata yang menyapanya adalah anak bertas sepatu balet. (SK-I/I6)

Kutipan (8) menunjukkan tindakan refleks yang terjadi pada Lilian. Ketika merasa mengantuk, Lilian mencoba beberapa kali memejamkan mata. Namun, karena belum mengantuk, Lilian tidak juga tertidur. Kutipan (9) menunjukkan bahwa id secara refleks merespons rangsangan yang berasal dari luar. Ketika asyik mengunyah permen, Lilian dikejutkan dengan suara dan tepukan yang berasal dari arah belakang. Hal tersebut membuat Lilian secara refleks langsung menoleh ke arah sumber suara tersebut. Rosmila, et al (2020) dalam mereduksi ketegangan/menghilangkan kondisi tidak menyenangkan dan untuk memperoleh kesenangan, id menempuh dua cara yaitu refleks dan primer. Refleks merupakan reaksi mekanis/otomatis bersifat bawaan, seperti: bersin dan berkedip. Melalui refleks, ketegangan (perasaan tidak nyaman) dapat direduksi dengan segera.

\section{Struktur Kepribadian Ego Tokoh Lilian}

Ego merupakan aspek psikologi kepribadian dan timbul karena kebutuhan organisme untuk berhubungan secara baik dengan dunia kenyataan, merupakan pelaksanaan dari kepribadian yang mengontrol dan memerintah id serta superego. Abraham (2017) menyebutkan Ego adalah pelaksana dari kepribadian, yang memiliki dua tugas utama; pertama, memilih stimuli mana yang hendak direspon dan atau insting mana yang akan dipuaskan sesuai dengan prioritas kebutuhan. Kedua, menentukan kapan dan bagaimana kebutuhan itu dipuaskan sesuai dengan tersedianya peluang yang risikonya minimal.

Identifikasi data yang didapat pada tokoh Lilian yang dominan terhadap ego merupakan kepribadian tokoh Lilian dalam membedakan khayalan dan kenyataan. Data ini berhubungan dengan dunia batin Lilian yang diwujudkan dalam perbuatan. Tindakan nyata mencapai tujuan yang diinginkan seperti ketika lapar langsung mencari makan. Hal itu terdapat dalam kutipan berikut.

Lilian mendengus kesal. Hari pertamanya mendadak kacau begini, tidak ada teman satu

(I) pun. Langsung saja, dia berjalan menuju tasnya untuk mengambil permen. Rupanya dia merasa lapar. (SK-E/I5)

Hap! Lilian memasukkan permen jeli ke mulut kecilnya. Nyam...nyam... manis sekali rasanya (SK-E/I6)

Mama membawakanku bekal apa, ya? Gumam Lilian dalam hati. Cepat-cepat, Lilian membuka kotak makannya yang berwarna kuning kunyit. Ada sosis yang sudah dipotong-potong dan kentang goreng. Hmmmm...kelihatannya enaaak! Batin Lilian berkata-kata. (SK-E/40)

Nawawi \& Ahsana (202I) cara kerja ego berpegang pada prinsip kenyataan (the reality principle) dan bereaksi dengan proses sekunder. Prinsip ini bertujuan menemukan objek yang tepat agar dapat mereduksi ketegangan yang timbul pada organisme. Orang yang lapar perlu makan untuk menghilangkan ketegangan yang ada pada dirinya. Kutipan (I) diatas menunjukkan cara yang dilakukan Lilian untuk meredakan ketegangan ketika pertama masuk sekolah karena tidak dihiraukan temannya. Lilian berusaha menyapa Olla temannya ketika TK. Tetapi, karena Lilian tergolong anak yang tidak mudah bergaul dan tidak memiliki banyak teman, sehingga Olla tidak merasa mengenal Lilian meskipun Lilian sudah menjelaskan bahwa mereka pernah bersekolah di TK yang sama. Sikap acuh Olla membuat Lilian merasa sangat kesal. Kemudian Lilian merasa lapar. Tindakan nyata untuk memenuhi rasa lapar dengan pergi menuju tasnya untuk mengunyah permen. Rosmila, et al (2020) ego terbentuk pada struktur kepribadian individu sebagai hasil kontak dari dunia luar. Sebagai satu-satunya area pikiran yang berinteraksi dengan dunia luar, ego berperan sebagai pengambil keputusan atau cabang eksekutif dari kepribadian. Adapun proses yang dimiliki dan dijalankan ego sehubungan dengan upaya memuaskan kebutuhan atau 
mengurangi tegangan oleh individu adalah proses sekunder (secondary process). Proses sekunder adalah proses berpikir realistis; dengan mempergunakan proses sekunder, ego merumuskan suatu rencana untuk pemuasan kebutuhan dan mengujinya (biasanya dengan suatu tindakan).

Rasa lapar tersebut dihilangkan dengan cara menikmati mengunyah permen, seperti pada kutipan (2) Lilian dengan asyiknya mengunyak permen. Dia begitu menikmati permen tersebut dan berusaha melupakan sikap Olla yang tidak mengenalnya. Pemilihan permen berhubungan dengan kebiasaan anak kecil yang suka makan-makanan yang manis termasuk permen. Anak kecil menganggap permen merupakan makanan yang dapat dimakan dimana pun. Ego berkembang dari id, ketika manusia mulai meninggalkan kekanak-kanakannya, sebagai bentuk respons terhadap realitas. Ego bersifat sadar dan rasional. Keinginan-keinginan id tidak selalu dapat dipenuhi, dan ketika itulah ego memainkan peranan. Ego bekerja berdasarkan prinsip realitas. Aspek ego dipandang sebagai aspek spekulatif kepribadian. Yarta, et al (2012) ego mendasarkan dirinya pada prinsip realitas, sehingga seseorang dapat memanipulasi id agar memuaskan instingnya dengan tetap mempertahankan masukan dari luar, maka ego dapat membedakan sesuatu yang hanya ada di dalam batin dan sesuatu yang ada diluar dunia objektif dan realitas.

Balet, kan, kursus yang diikuti oleh lavender, ujar Lilian dalam hati."Kelihatannya asyik juga kalau aku coba-coba dulu," Lilian akhirnya menyetujui keinginan mama. Lilian pun segera menaruh majalah itu di atas meja, dekat tempat duduknya. "Jadi... oke, kan?" tanya mama pendek. Lilian mengangguk cepat (SK-E/30)

Gerakan balet ternyata tidak semudah yang Lilian bayangkan. Hanya saja, Miss natalie yang lincah membuat semunya menjadi terlihat mudah. Pertama, mereka berlatih melompat atau skipping. "Satu...dua... ayo, semuanya semangat. Ikuti irama musiknya,

(5) ya!” perintah Miss Natalie. Satu jam tidak terasa berlalu begitu cepat. Les pun berakhir. Peluh Lilian bercucuran. Wah, seperti olahraga senam saja, lho. Sungguh menyenangkan. Kurasa, aku akan menyukai berlatih balet. Badanku terasa lentur dan teman-temanku semua baik, batin Lilian, meyakinkan dirinya (SK-E/67)

Rosmila, et al (2020) menyebutkan ego adalah aspek psikologis kepribadian yang berada di antara alam sadar dan alam bawah sadar. Ego merupakan sebuah hasil dari pertimbangan superego yang berupa tindakan atau upaya yang dilakukan seseorang untuk memenuhi tuntutan id. Pada kutipan (4) menunjukkan ego Lilian yang ingin lebih dekat dengan Lavender sahabatnya. Cara yang ditempuh untuk mencapai keinginan tersebut adalah mengikuti kemauan mama mengikuti les balet yang juga diikuti oleh Lavender. Lilian berharap dengan mengikuti les balet yang juga diikuti oleh Lavender akan membuat persahabatan mereka semakin erat. Suprapto (2018) bahwa ego memberi tempat pada fungsi mental utama, seperti penalaran, penyelesaian masalah, pengambilan keputusan, dan memberi pertimbangan pada manusia apakah ia mampu memuaskan diri tanpa mengakibatkan kesulitan bagi dirinya sendiri.

Kutipan (5) menunjukkan keseriusan Lilian belajar balet. Pada awalnya Lilian membayangkan kesulitan untuk berlatih balet. Prahasita (2014) menyebutkan ego berkembang dari id agar individu mampu menangani realita sehingga ego beroperasi mengikuti prinsip realita. Ego berusaha memperoleh kepuasan yang dituntut id dengan mencegah terjadinya tegangan baru atau menunda kenikmatan sampai ditemukan objek yang nyata-nyata dapat memuaskan kebutuhan. Namun, karena guru baletnya baik dan sabar, akhirnya Lilian mulai menyukai balet dan memutuskan untuk terus ikut les balet. Selain itu, juga dipengaruhi oleh keinginan Lilian untuk dekat dengan Lavender. Dari kutipan diatas dapat diketahui bahwa dorongan-dorongan yang dirasakan oleh Lilian harus tetap dipuaskan. Upaya yang dilakukan Lilian untuk memuaskan keinginannya untuk lebih dekat dengan Lavender dengan cara mengikuti les balet.

\section{Struktur Kepribadian Superego Tokoh Lilian}

Freud dalam Dani \& Adji (202I) superego merupakan internalisasi, artinya larangan atau perintah dari luar akan diproses dan akan terpancar dalam diri. Larangan-larangan dan perintah-perintah 
yang berasal dari "asing" kemudian dianggap sebagai sesuatu yang berasal dari subjek. "Engkau tidak boleh... atau engkau harus..." menjadi "Aku tidak boleh... atau aku harus...”. Tokoh Lilian yang terdapat dalam novel Pick Cupcake memiliki superego yang terbentuk akibat interaksi dengan lingkungan sekitar. Tokoh Lilian yang terdapat dalam novel anak ini memiliki interaksi dengan orang tua, temanteman di sekolah, guru, maupun orang-orang yang dekat dengan tokoh. Wujud dari internalisasi yang berhubungan dengan nilai dalam masyarakat berupa sopan-santun, benar atau salah, hukuman dari kesalahan, peringatan, dan pujian.

(I) “Olla! Kamu sedang apa, sih?” sapanya berusaha santun. (SK-E/I4)

(2) "Lilian, Tante. Baru kenalan sama Lavender tadi pagi," ucap Lilian sopan. (SK-SE/22)

"Lilian, ayo masuk kelas! Tuh, bel sudah berbunyi." Bu Guru tiba-tiba mengajak masuk Lilian. "Eh, iya. Maaf Bu...," Lilian bergegas menuju kelasnya. (SK-SE/36-37)

"Eh, ada Lilian dan Olla. Kok ngobrol di sini? Jangan lama-lama di kamar mandiI" tegur

(4) guru perempuan itu. Olla dan Lilian mengangguk sopan, Iya, Bu. Cuma sebentar, kok." (SK-SE/134)

"Nah, Lilian," kata mama menasihati, "kamu hati-hati, ya. Mama harus ke kantor cepat-

(5) cepat. Sayang sekali, Ayah sedang sibuk dinas di luar kota." Lilian hanya menganggukangguk (SK-SE/I3)

(6) Dengan sabar, dia menunggu jemputan. Tidak lama kemudian, sebuah mobil sedan yang berwarna silver memasuki tempat parkir sekolah. (SK-SE/24)

"Lilian, ayo, cepat sedikit, dong! Lihat sudah jam berapa sekarang," mama berkata masam. Lilian pun menuruti mamanya. Dia langsung masuk ke mobil. (SK-SE/72)

Ayah menjawab, "Iya. Cepat, dong, Nak. Penting, nih.” Dengan lemas, Lilian

menyodorkan handphone kepada Mama yang sibuk menyetir (SK-SE/53)

Hmmm...ternyata, Mbak Yuni benar juga, ya. Melahirkan itu lama sekali, guman Lilian dalam hati sambil menguap lebar. (SK-SE/I I4)

Kutipan (I) menunjukkan bahwa sebagai anak Lilian berusaha menghormati sesamanya, bukan hanya kepada orang yang lebih tua tetapi juga kepada orang yang sebaya dengan dirinya, yaitu Olla teman sekelasnya. Hal ini ditunjukkan dengan kesantunan Lilian ketika menyapa Olla. Olla merupakan teman Lilian ketika mereka masih TK. Lilian yang sejak TK jarang bergaul, sehingga tidak banyak memiliki teman. Ketika Lilian tahu kalau Olla setu sekolah lagi, Lilian berusaha menyapa meskipun pada akhirnya Olla bersikap cuek dan tidak peduli dengan Lilian. Sikap Lilian ini bersumber dari superego Lilian yang mulai mampu untuk menunjukkan moralitas. Superego merupakan aspek sosiologis dari kepribadian seperti yang dijelaskan oleh Maftuhah (2018) superego merupakan wakil dari nilai-nilai tradisional serta cita-cita dan dianggap sebagai aspek moral dari kepribadian.

Kutipan (2) menunjukkan sikap Lilian ketika pertama kali bertemu dengan Ibu dari Lavender. Lilian bersikap sangat sopan ketika Ibu dari Lavender mengajar berbicara. Sikap ini merupakan salah satu sikap Lilian yang menghormati orang yang lebih tua, apalagi pada orang yang beru dikenalnya. Sikap anak ini tentunya tidak lepas dari peran orang tua dalam mendidik anak untuk menghormati orang yang lebih tua. Hubungan ini dijelaskan Freud (dalam Piaget, 2010) menyebutkan bahwa terdapat hubungan afektif antara anak dan orang tua atau orang dewasa yang memainkan peran sebagai orang tua, melahirkan kepekaan moral tertentu yang dipaksakan pada seseorang oleh nuraninya. Hal ini dilakukan dengan cara Lilian menjawab sopan ketika ditanya oleh ibunya Lavender.

Kutipan (3) dan (4) menunjukkan sikap Lilian dalam menghormati gurunya. Lilian dengan sopan bahwa Lilian sangat menghormati gurunya. Lilian mematuhi perintah gurunya ketika guru mengajak untuk segera masuk kelas. Begitu juga ketika Lilian di tegur guru agar tidak terlalu lama mengobrol di kamar mandi. Bagi Lilian guru merupakan sosok yang menjadi panutan dan telah memberikan ilmu dan mengajari berbagai pelajaran di sekolah. Hal ini lah yang selalu diingat oleh Lilian seperti pendapat Sari (2020) menjelaskan bahwa perkembangan emosional pada masa kanak-kanak merupakan ujung tombak yang menentukan sikap, nilai, dan perilaku di masa depan. 
Sikap moral yang ditanamkan sejak dini akan memberikan dampak yang positif bagi perkembangan anak. Sikap moral ini merupakan bagian dari sistem kerja superego seperti yang disampaikan oleh Dani \& Adji (202I) cara kerja superego bersifat subjektif karena tergantung pada nilainilai yang dianut orang tua. Orang tua selalu mengajarkan supaya anaknya selalu mematuhi dan melaksanakan apa yang disampaikan oleh orang tua. Sebagai seorang anak Lilian pun memiliki kewajiban untuk mematuhi apa yang diucapkan oleh mamanya, mendengarkan segala nasihat mamanya. Kutipan (5) menunjukkan sikap Lilian yang mematuhi perintah dan nasihat yang telah disampaikan oleh mamanya. Mama memberi tahu jika ia harus segera pergi ke kantor setelah mengantar Lilian ke sekolah. Lilian yang mendengar ucapan mamanya segera menganggukkan kepala. Pada kutipan (6) menunjukkan kepatuhan Lilian terhadap nasihat mamanya untuk menunggu sampai mamanya datang. Lilian dengan sabar menunggu mamanya menjemput, meskipun sebenarnya mamanya sudah terlambat menjemputnya. Kutipan (7) menunjukkan bahwa Lilian mengikuti perintah mamanya. Keterlambatan mama menjemput Lilian membuat perasaan Lilian menjadi jengkel. Rasa jengkel ini ditunjukkan dengan sikap diam ketika mama menyuruh Lilian untuk segera masuk mobil. Meskipun jengkel, sebagai anak Lilian tetap mematuhi perintah mamanya. Sikap ini dapat berasal dari rasa takut kepada mama yang marah jika Lilian tidak menuruti perintah mama. Takut pada anak menurut Darmiah (2019) merupakan perasaan terancam oleh suatu objek yang membahayakan.

Moral Lilian yang berasal dari superego lebih didasarkan pada rasa takut dibandingkan dengan rasa cinta. Lilian takut mamanya akan marah jika ia tidak menuruti perintahnya seperti pada kutipan (8). Lilian selain harus mematuhi mamanya juga harus mematuhi perintah ayahnya. Perasaan jengkel muncul ketika Lilian ingin lebih lama mengobrol dengan ayahnya di telepon. Namun hal itu tidak terjadi karena ayahnya seolah-olah tidak memperdulikannya dan segera ingin berbicara dengan mamanya. Sikap ayahnya ini selain menimbulkan rasa kesal juga menimbulkan rasa cemburu. Lilian merasa cemburu kepada mamanya karena Lilian merasa ayahnya lebih suka berbicara dengan mamanya daripada berbicara dengan dia. Rasa cemburu yang dirasakan anak menurut Darmiah (2019) merupakan reaksi normal terhadap kehilangan kasih sayang yang nyata, dibayangkan, atau ancaman kehilangan kasih sayang. Meskipun Lilian keberatan dengan permintaan ayahnya yang segera ingin berbicara dengan mamanya. Namun, Lilian berusaha memahami untuk tetap patuh kepada orang tuanya. Hal ini membuat Lilian menuruti perintah ayahnya yang ingin segera berbicara dengan mamanya.

Kutipan (9) menunjukkan bahwa Lilian tidak hanya patuh pada orang tua, tetapi Lilian juga membenarkan ucapan Mbak Yuni yang merupakan pembantu di rumah Lilian. Awalnya Lilian ingin menunggu mama yang akan melahirkan di rumah sakit. Lilian tidak mau mendengarkan ucapan Mbak Yuni untuk tidur. Akhirnya karena kelelahan Mbak Yuni tertidur, sedangkan Lilian terus menunggu telepon dari ayahnya yang akan mengabarkan keadaan mama. Lama-kelamaan Lilian merasa lelah dan mengantuk dan Lilian membenarkan ucapan pembantunya untuk tidur. Ketidakpatuhan yang dilakukan Lilian merupakan salah satu bentuk kekhawatiran yang dirasakan anak terhadap kondisi orang tuanya. Rasa khawatir pada anak menurut Darmiah (2019) biasanya dijelaskan sebagai khayalan ketakutan atau gelisah tanpa alasan. Tidak seperti ketakutan yang nyata, rasa khawatir tidak langsung ditimbulkan oleh rangsangan dalam lingkungan tetapi merupakan produk pikiran anak itu sendiri. Rasa khawatir timbul karena membayangkan situasi berbahaya yang mungkin akan meningkat. Kekhawatiran merupakan hal normal pada masa kanak-kanak, bahkan pada anak-anak yang penyesuaiannya paling baik sekalipun.

Wujud superego dapat ditunjukkan dengan keinginan untuk diterima dalam kelompok sosial. Lilian selalu ingin menjaga hubungan baik dengan temannya, sehingga ia memaafkan kesalahan temannya. Hal itu terdapat dalam kutipan berikut.

(I0) "Iya, enggak apa-apa, kok ...," ujar Lilian sambil tersenyum lega (SK-SE/43)

Kutipan (I0) menunjukkan upaya Lilian dalam membina hubungan baik dengan orang di sekitarnya. Lilian telah memaafkan perbuatan Olla yang sudah dengan sengaja menjatuhkan kue 
favoritnya. Marsari (202I) pada proses pembelajaran di sekolah dasar, anak akan mulai berinteraksi dengan teman sebaya dan orang dewasa lainnya. Pada masa ini anak usia sekolah dasar tidak hanya saja harus menguasai emosi dirinya sendiri namun juga harus mampu menguasai emosi nya kepada orang lain.

Keinginan Lilian untuk diterima dalam kelompok sosial, yaitu keinginan menghadiri pesta ulang tahun Olla. Hal itu terdapat dalam kutipan berikut.

"Hai, Olla. Sedang nulis apa?" tanyanya ramah. Temannya melirik dengan ekor matanya, berhenti menulis. "Nama anak-anak yang akan diundang untuk pesta ulang tahun ku," jawab Olla dengan angkuhnya. Mata Lilian langsung bersinar. Dia melongok-longok ke kertas yang dipegang oleh Olla, berharap namanya ada. "Namamu belum aku catat di sini. Memangnya kamu bisa datang?" Olla bertanya judes. Lilian tidak tersinggung. Yang penting, dia ingin diundang. (SK-SE/I32)

Kutipan (II) menunjukkan keinginan Lilian untuk diundang pada pesta ulang tahun Olla yang terkenal sangat meriah dan hanya dihadiri oleh teman dekatnya saja. Lilian ingin sekali datang ke pesta ulang tahun tersebut, meskipun awalnya Olla tidak berniat mengundangnya. Namun, karena Lilian sedikit mendesak akhirnya Olla mengundang Lilian ke ulang tahunnya. Darmiah (2019) rangsangan yang menimbulkan keingintahuan anak-anak sangat banyak. Anak-anak menaruh minat terhadap segala sesuatu di lingkungan mereka. Pada usia 8-I0 tahun anak memiliki keinginan untuk diterima sebagai anggota kelompok teman sebaya. Kebanyakan anak merasa bahwa untuk diterima, mereka haruslah konformis sedekat mungkin dengan pola-pola yang terbentuk di kelompok.

Pertengkaran antar teman sebaya bahkan teman akrab sering terjadi pada masa kana-kanak. Hal itu terjadi karena beberapa hal, seperti berbedaan pendapat atau kesalahpahaman. Namun, pertengkaran tersebut tidak berlangsung lama dan mudah akrab kembali. Hal tersebut terdapat dalam kutipan berikut.

Lavender menarik nafas panjang. "Ya...aku maafkan, deh,” ujar Lavender pendek. Lilian menarik tangan sahabatnya dan memeluknya. "Aku janji tidak akan melakukannya lagi...” (SK-SE/123)

Kutipan (I2) menunjukkan keinginan Lilian untuk menjalin persahabatan kembali dengan Lavender setelah mereka bertengkar. Lilian berjanji tidak akan mengulangi perbuatan yang membuat mereka bertengkar. Marsari (202I) setiap fase perkembangan yang dilalui oleh anak akan mengalami konflik dan biasanya anak akan selalu sukses dalam menyelesaikan konflik tersebut. Namun apabila anak tidak menjumpai adanya konflik selama fase perkembangan maka kemungkinan besar anak mengalami gangguan emosi.

Bagi anak-anak memiliki teman akrab sangat menyenangkan, apalagi di usia-usia sekolah, selain untuk diajak bermain, memiliki komunitas sosial, teman akrab juga dapat diajak untuk berbagi cerita. Hal itu terdapat dalam kutipan berikut.

(I3) karena orang tua kita hanya memperhatikan adik saja sebal" Lilian tampak sewot.

(SK-SE/I24)

Kutipan (I3) menunjukkan pelampiasan kekesalan Lilian karena mama hanya memperhatikan adiknya kepada Lavender. Lilian berharap dengan bercerita kepada sahabatnya, rasa kesalnya akan berkurang. Wujud superego juga dapat dilihat dari cara tokoh meminta keadilan akibat perbuatan orang lain. Hal tersebut terdapat pada kutipan data berikut ini. 
Lilian yang menahan tangis mengangguk. Dengan berani, dia segera beranjak dari duduknya, mengejar Olla, dan menepuk pundak Olla. "Hei! Kamu minta maaf dong. Kamu berbuat salah tadi," Lilian memberanikan diri (SK-SE/43)

Kutipan (I4) menunjukkan sikap Lilian yang merasa disakiti oleh Olla teman sekelasnya yang telah sengaja menjatuhkan kue favoritnya yang menjadi bekal untuk makan siang di sekolah. Akibat perbuatan Olla, kue bekal Lilian tidak dapat dimakan lagi dan Olla justru pergi begitu saja tanpa meminta maaf. Hal tersebut membuat Lilian merasa telah disakiti, sehingga Lilian berani mengambil keputusan menghampiri dan memarahi Olla. Hal ini menunjukkan bahwa egonya harus bertindak untuk memperoleh kejadian membela dirinya sendiri. Yarta, et al (2012) aspek superego mempunyai fungsi menentukan sesuatu apakah benar atau salah, pantas atau tidak, susila atau asusila, dengan demikian sesuai dengan masyarakat.

Ayah tertawa. "Makanya, ngambek enggak enak, kan? Lain kali, kalau ngambek lagi,

(I5) Ayah benar-benar akan hukum kamu, lho!" candanya. Lilian langsung menggelenggelengkan kepalanya, "enggak mau dihukum!". (SK-SE/90-9I)

Kutipan (I5) menunjukkan sebuah peringatan yang disampaikan oleh ayah kepada Lilian tentang hukuman yang akan diberikan jika Lilian marah lagi. Bovet (dalam Piaget, 2010) menyebutkan bahwa sentimen juga merupakan salah satu rasa hormat dan mengandung afeksi dan rasa takut.

(I6) Lilian tersipu malu karena dia merasa beruntung diajari oleh Miss Natalie. (SK-SE/70)

Lilian tersenyum senang. Pipinya mendadak merah merona karena malu dipuji. (SK$\mathrm{SE} / 94)$

Kutipan (I6) menunjukkan Lilian merasa malu karena dipuji oleh Lavender karena beruntung mendapat guru baik seperti Miss Natalie. Darmiah (2019) rasa malu merupakan bentuk ketakutan yang ditandai oleh penarikan diri dari hubungan dengan orang lain yang tidak dikenal atau tidak sering berjumpa. Pada kutipan (I7) juga menunjukkan ekspresi Lilian ketika mendapat pujian dari ayahnya karena telah memberikan kartu ucapan untuk ayahnya. Darmiah (2019) kegembiraan adalah emosi yang menyenangkan yang juga dikenal dengan keriangan, kesenangan, atau kebahagiaan. Setiap anak berbeda beda intensitas kegembiraan dan jumlah kegembiraannya serta cara mengekspresikannya sampai batasbatas tertentu.

\section{SIMPULAN}

Penelitian tentang struktur kepribadian tokoh Lilian dalam novel anak Pink Cupcake Karya Ramya Hayasrestha Sukarni memiliki kesimpulan sebagai berikut. Pada struktur kepribadian aspek id pada tokoh Lilian menjadi aspek dominan ketika tokoh ingin mengejar kesenangan untuk menghindari rasa sakit. Aspek id pada Lilian sangat mempengaruhi aspek ego dan superego. Lilian selalu membayangkan sesuatu yang diinginkannya. Wujud dari id yang dilakukan Lilian berhubungan dengan subjektivitas individu berupa perasaan, persepsi, gambaran, ingatan, gagasan, dan halusinasi. Perasaan Lilian dapat berupa rasa senang, sedih, bahagia, dan iri. Id pada Lilian dapat menggunakan berbagai cara irasional, impulsif, dan suka kesenangan. Lilian dalam mengurangi ketegangan melakukan tindakan refleks bersin, berkedip, dan rasa kaget dari panggilan atau tepukan.

Struktur kepribadian aspek ego pada Lilian merupakan kepribadian Lilian dalam membedakan khayalan dan kenyataan. Dunia batin Lilian yang diwujudkan dalam perbuatan dan tindakan nyata untuk mencapai tujuan yang diinginkan seperti ketika lapar langsung mencari makan. Struktur kepribadian superego tokoh Lilian memiliki interaksi dengan orang tua, teman-teman di sekolah, guru, maupun orangorang yang dekat dengan Lilian. Wujud dari internalisasi yang berhubungan dengan nilai dalam 
masyarakat berupa sikap dan perbuatan Lilian dalam bersikap sopan, pemahaman benar atau salah, hukuman dari kesalahan, peringatan, dan pujian.

Kontribusi penelitian ini bagi anak-anak maupun siswa, yaitu dapat memberikan bacaan yang sesuai dengan perkembangan psikologinya. Sastra anak yang ditulis anak akan mudah dipahami oleh anak karena cerita, tokoh, bahasa, dan setting mudah dipahami oleh anak. Selain itu, dapat digunakan sebagai motivasi untuk anak-anak maupun siswa untuk dapat mengungkapkan ide dan imajinasinya dalam bentuk cerita. Kontribusi untuk pendidikan, sastra anak akan menjadi bacaan untuk anak sesuai dengan usianya. Membaca sastra anak akan mengajarkan tentang karakter-karakter anak yang boleh dan tidak boleh ditiru.

\section{UCAPAN TERIMA KASIH}

Peneliti mengucapkan terima kasih kepada Program Studi Pendidikan Bahasa dan Sastra Indonesia, Fakultas Pendidikan Ilmu Sosial dan Humaniora, IKIP Budi Utomo yang telah memberikan dukungan dalam penelitian ini, sehingga penelitian ini dapat terlaksana dan diselesaikan dengan baik.

\section{DAFTAR PUSTAKA}

Abraham, Ihsan. (2017). Struktur kepribadian tokoh dalam novel Surat Kecil untuk Tuhan Karya Agnes Davonar. KEMBARA: Jumal Keilmuan Bahasa, Sastra, dan Pengajarannya (e-Journal), 3(I), 5563. https://doi.org/I0.22219/kembara.v3iI.4378

Alwisol. (20II). Psikologi kepribadian. Malang: UMM Press.

Anggraini, Purwati. (2016). Citra tokoh perempuan dalam cerita anak Indonesia (Sebuah pendekatan kritik feminisme). KEMBARA: Jumal Keilmuan Bahasa, Sastra, dan Pengajarannya (e-Journal), 2(I), 67-76. https://doi.org/I0.222I9/kembara.v2iI.4045

Dani, Agustine Tryas dan Adji, Peni. (202I). Struktur kepribadian tokoh utama dalam novel Anak Bungsu karya Soesilo Toer. Jurnal Ilmiah Kebudayaan SINTESIS, I5(I), 57-66. https://doi.org/I0.2407I/sin.vI5iI.32I2

Darmiah. (2019). Perkembangan dan faktor-faktor yang mempengaruhi emosi anak usia MI. Jurnal Pioner: Jurnal Pendidikan, 8(2), I-IO.

Dewi, M. P., Neviyarni, S., \& Irdamurni, I. (2020). Perkembangan bahasa, emosi, dan sosial anak usia sekolah dasar. Jumnal Ilmiah Pendidikan Dasar, 7 I), I-II. http://dx.doi.org/I0.30659/pendas.7.I.I-II

Efendi, M. F., Hudiyono, Y., \& Murtadlo, A. (2019). Analisis cerita rakyat Miaduka ditinjau dari kajian sastra anak. Jurnal Ilmu Budaya 3(3). 246-257.

Faidah, Citra Nur. (2018). Dekonstruksi sastra anak: Mengubah paradigma kekerasan dan seksualitas pada karya sastra anak Indonesia. Jurnal Kredo, 2(I), I26-I39. https://doi.org/I0.24I76/kredo.v2iI.2458

Gunawan, A. R., \& Putro, S. S. (2020). Analisis Semiotika pada bacaan sastra anak raden legowo: Pahlawan dari hutan perewangan karya Sulistiati dengan perspektif religiusitas. Jurnal Salaka: Jurnal Bahasa, Sastra, dan Budaya Indonesia, 2(I). 3-I 5. I0.3375I/jurnal salaka.v2iI.I 833

Husin. (20I7). Id, ego dan superego dalam pendidikan Islam. Jurnal Ilmiah Al-QALAM, II(23), 4764. http:/ /dx.doi.org/I0.3593I/aq.v0i0.3

Ikhwan, W. K. (20I3). Upaya menumbuhkan karakter anak dalam pembelajaran sastra anak dengan model play-learning dan performance-art learning di SDN Banyuajuh 4. Widyagogik: Jurnal Pendidikan dan Pembelajaran Sekolah Dasar, I(I), 70-84. https://doi.org/I0.2II07/widyagogik.vIiI.6

Ilham. (2020). Perkembangan emosi dan sosial pada anak usia sekolah dasar. EL-Muhbib Jurnal Pemikiran dan Penelitian Pendidikan Dasar, 4(I), I62-I80.

Ja'far, S. (2015). Struktur kepribadian manusia perspektif psikologi dan filsafat. Psympathic: Jurnal Ilmiah Psikologi, 2(2), 209-22I. https://doi.org/I0.15575/psy.v2i2.46I 
Khasanah, N., Hamzani, A. I., \& Aravik, H. (202I). Dinamika kepribadian dalam perspektif psikologi Islam; Telaah konsep amarah, lawwamah, dan muthmainnah serta korelasinya dengan iman, Islam, dan ihsan. SALAM: Jurnal Sosial dan Budaya Syar-i, 8(2), 60I-6I4. https://doi.org/I0.15408/sjsbs.v8i2.2003I

Kurniawan, Heru. (20I3). Sastra anak dalam kajian strukturalisme, sosiolohi, semiotika, hingga penulisan artikel kreatif. Yogyakarta: Graha Ilmu.

Maftuhah, M. (2019). Kepribadian tokoh utama dalam novel Rembulan Tenggelam di Wajahmu karya Tere Liye (Kajian psikoanalisis Sigmund Freud). EDU-KATA, 5(2), I2I-I28. https://doi.org/I0.52166/kata.v4i2.I0I3

Marsari, H., Neviyarni, N., \& Irdamurni, I. (202I). Perkembangan emosi anak usia sekolah dasar. Jurnal Pendidikan Tambusai, 5(I), I816-1822. Retrieved from https://jptam.org/index.php/jptam/article/view/II82

Miles, M. B., \& Huberman, A. M. (1994). Qualitative data analysis: An expanded sourcebook. Sage: Sage Publications.

Minderop, Albertime. (2010). Psikologi Sastra: Karya sastra, metode, teori, dan contoh kasus. Jakarta: Yayasan Pustaka Obor Indonesia.

Munaris. (2020). Sastra anak sebagai sarana pendidikan karakter di sekolah. Jurnal KATA (Bahasa, Sastra dan Pembelajarannya), 4(2), I-IO.

Nawawi, M., \& AS, C. A. (202I). Struktur kepribadian tokoh utama dalam cerpen "Ash-Shabiyul A'raj" karya Taufiq Yusuf Awwad (Kajian psikoanalisis Sigmund Freud). An-Nahdah al'Arabiyah, I I I ), I30-I47. Retrieved from https://journal.arraniry.ac.id/index.php/nahdah/article/view/726

Nurgiyantoro, Burhan. (2010). Sastra anak pengantar pemahaman dunia anak. Yogyakarta: University Press.

Prahasita, Naratungga Indit. (20I4). Kepribadian tokoh utama dalam novel Nyanyian Batanghari karya Harry B. Kori'un. Jurnal Gramatika, 2(2), IIO-I23.

Piaget, Jean. (2010). Psikologi anak. Terjemahan Miftahul Jannah. Yogyakarta: Pustaka Pelajar.

Rosid, Abdul. (202I). Nilai-nilai dalam sastra anak sebagai sarana pembentukan karakter. Metalingua Jurnal Pendidikan Bahasa dan Sastra Indonesia, 6(I), I-IO. https://doi.org/I0.21107/metalingua.v6iI.10508

Rosmila, A., Sulistyowati, E. D., \& Sari, N. A. (2020). Kepribadian tokoh utama dalam novel Kanvas karya Bintang Purwanda: Kajian psikologi sastra. Ilmu Budaya: Jumnal Bahasa, Seni, dan Budaya, 4(2), 330-340. http://dx.doi.org/I0.30872/jbssb.v4i2.2739

Rumaf, N., Jumroh, A., \& Fatihaturrahmah, S. (2018). Representasi kebebasan tokoh utama dalam novel Trilogi Soekram karya Sapardi Djoko Damono (Tinjauan eksistensialisme). KEMBARA: Jurnal Keilmuan Bahasa, Sastra, dan Pengajarannya (e-Journal), 4(2), 192-199. https://doi.org/I0.22219/kembara.v4i2.5983

Rumidjan. (2013). Dasar keilmuan dan pembelajaran sastra anak SD. Malang: FIP UM.

Sarumpaet, Riris K. Toha. (20I0). Pedoman penelitian sastra anak. Jakarta: Yayasan Obor Indonesia.

Sari, P. P., Sumardi, S., \& Mulyadi, S. (2020). Pola asuh orang tua terhadap perkembangan emosional anak usia dini. Jurnal PAUD Agapedia, 4(I), I57-170. https://doi.org/I0.17509/jpa.v4iI.27206

Sembiring, R. H., Herlina, H., \& Attas, S. G. (2018). Kepribadian tokoh utama dalam novel Negeri Para Bedebah karya Tere Liye kajian psikoanalisis Carl Gustav Jung. Transformatika: Jurnal Bahasa, Sastra, dan Pengajarannya, 2(2), I57-172. 10.31002/transformatika.v2i2.788

Sartika. (2017). Struktur kepribadian tokoh utama Tania dalam novel "Daun yang Jatuh Tak Pernah Membenci Angin” karya Tere Liye. Jurnal Bahasa dan Sastra, 2(I), 45-52. Retrieved from https://core.ac.uk/download/pdf/28971373I.pdf 
Setyorini, R. (2017). Analisis kepribadian tokoh marni kajian psikologi Sigmund Freud dalam novel Entrok karya Okky Madasari. Kajian Linguistik dan Sastra, 2(I), I2-24. https://journals.ums.ac.id/index.php/KLS/article/view/5348

Sorraya, A., \& Rachman, A. K. (202I). Struktur kepribadian pada aspek ID tokoh utama dalam novel $D i$ Balik Kabut Amnesia karya Mira W. Paradigma: Jumnal Filsafat, Sains, Teknologi, dan Sosial Budaya, 27 I), 47-56. https:// doi.org/I0.33503/paradigma.v27iI.I287

Suprapto, S. (2019). Kepribadian tokoh dalam novel Jalan Tak Ada Ujung karya Muchtar Lubis kajian psikoanalisis Sigmund Freud. Metafora: Jurnal Pembelajaran Bahasa dan Sastra, 5(I), 54-69. I0.30595/mtf.v5iI.5028

Syam, E., \& Rosaliza, M. (2020). Kajian struktur kepribadian Freud dalam kisah IO0I malam: Studi psikoanalisis. Jurnal Ilmu Budaya, I7 I), I-I6. https://doi.org/I0.3I849/jib.vI7iI.4708

Yarta, A. H., Nurizzati, N., \& Nst, B. (2012). Kepribadian Tokoh utama dalam novel Sebelas Patriot karya Andrea Hirata: Kajian psikoanalisis. Jurnal Pendidikan Bahasa dan Sastra Indonesia, I(I), 254-262. https://doi.org/I0.24036/3I5-019883

Zubaidah, E. (200I). Pemanfaatan sastra anak-anak dalam evaluasi pembelajaran bahasa Indonesia di sekolah dasar. Jurnal Ilmiah Guru Caraka Olah Pikir Edukatif, 5(2). I-7. Retrieved from https://journal.uny.ac.id/index.php/cope/article/view/5356 